\title{
Epigenetics in plant tissue culture
}

\author{
M. J. M. Smulders • G. J. de Klerk
}

Received: 28 April 2010/ Accepted: 20 September 2010/Published online: 8 October 2010

(C) The Author(s) 2010. This article is published with open access at Springerlink.com

\begin{abstract}
Plants produced vegetatively in tissue culture may differ from the plants from which they have been derived. Two major classes of off-types occur: genetic ones and epigenetic ones. This review is about epigenetic aberrations. We discuss recent studies that have uncovered epigenetic modifications at the molecular level, viz., changes in DNA methylation and alterations of histone methylation or acetylation. Various studies have been carried out with animals, and with plant cells or tissues that have grown in tissue culture but only little work has been done with shoots generated by axillary branching. We present various molecular methods that are being used to measure epigenetic variation. In micropropagated plants mostly differences in DNA methylation have been examined. Epigenetic changes are thought to underlie various well-known tissue-culture phenomena including rejuvenation, habituation, and morphological changes such as flower abnormalities, bushiness, and tumorous outgrowths in, among others, oil palm, gerbera, Zantedeschia and rhododendron.
\end{abstract}

Keywords Methylation - Micropropagation - Off-types · Rejuvenation $\cdot$ Habituation

\section{Introduction}

In tissue culture, new plants may be generated by outgrowth of axillary buds or by adventitious regeneration (De

This paper is dedicated to Dr. A. F. (Ton) Croes (1935-2009), friend, teacher and reference point.

M. J. M. Smulders $(\bowtie)$ · G. J. de Klerk

Wageningen UR Plant Breeding, P.O. Box 16,

6700 AA Wageningen, The Netherlands

e-mail: rene.smulders@wur.nl
Klerk 2009). Researchers expected initially that these clonally propagated plants would be exact copies of the parent plant, but frequently aberrant plants were observed. Various causes have been established:

- Genetic changes (also referred to as somaclonal variation): changes in the DNA sequence;

- Epigenetic variation: long-lasting changes in the expression of the information in the genome;

- And-less relevant for this review-chimeral segregation and loss of pathogens, in particular viruses.

Various types of genetic changes have been observed including polyploidy, aneuploidy, (point) mutations, and new insertions of (retro) transposons. In crosses, mutations behave as Mendelian traits, with the notable exception of plants that become 'normal' when an inserted transposon jumps out again. Epigenetic changes are caused by changes in the expression of the information in the DNA brought about by alterations in DNA methylation, in histones, or in both. These modifications may influence gene transcription. Epigenetic changes are often temporary and plants may revert to the normal phenotype relatively easily, but some can be long lasting and may even be transferred during sexual propagation (Brettell and Dennis 1991) (Fig. 1). The latter occurs regularly in plants as epigenetic marks are not systematically erased in embryogenesis, as they are in mammals, and this leads to inheritable epimutations (epialleles) (Jullien and Berger 2010). Johannes et al. (2009) detected epigenetic changes in Arabidopsis thaliana that were stable for at least eight generations.

It is characteristic for epigenetic changes that in a population of generated plants the same aberration occurs at high frequency and can be 'reproduced' when the same conditions are imposed during the production of another population (Smulders et al. 1995). In contrast, genetic 
Fig. 1 Schematic representation of the differences between genetic and epigenetic variation. Note that during the various indicated tissue culture processes, the extent of genetic variation remains the same, but the extent of epigenetic variation is sharply reduced. In plants some epigenetic changes may survive sexual propagation

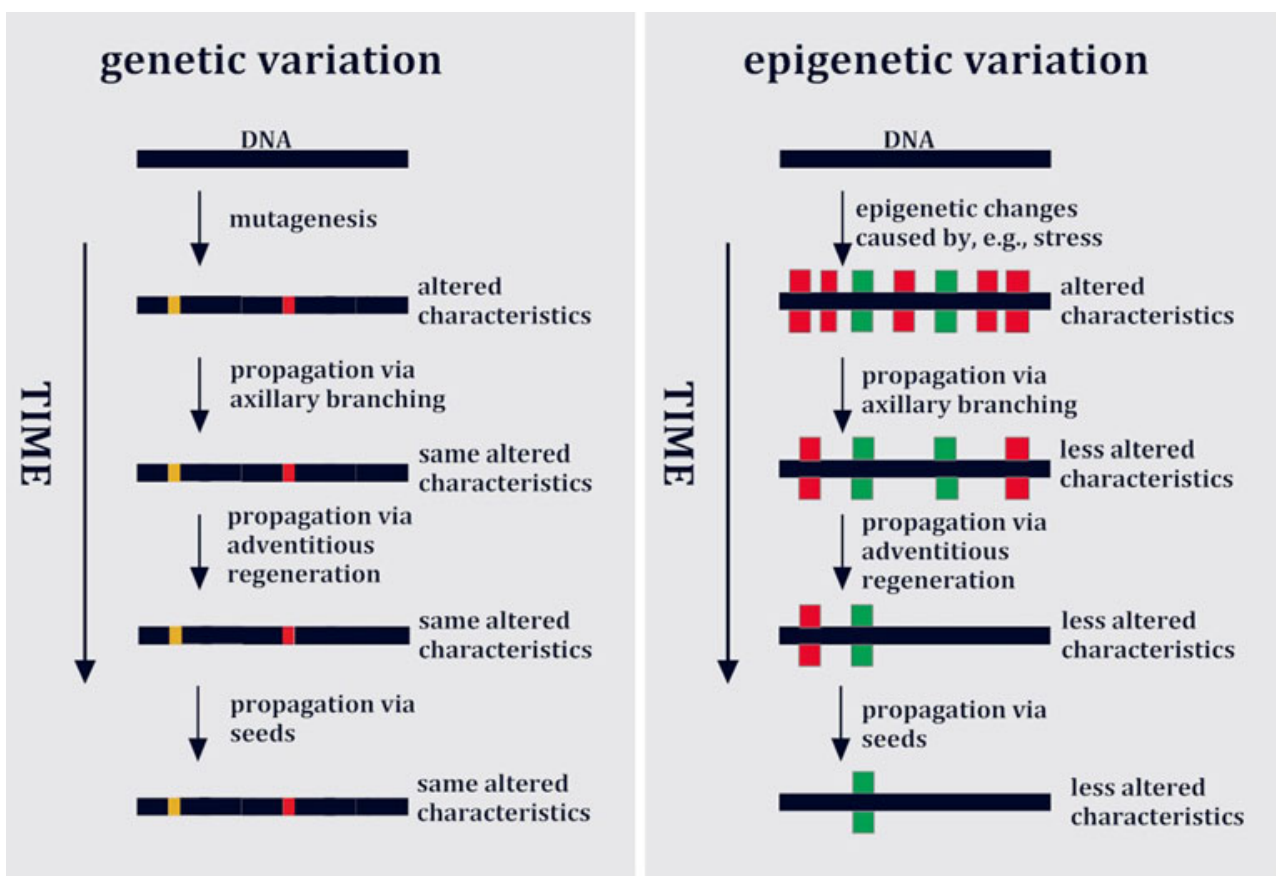

changes occur at random. It should be noted that in a somaclonal population the same genetic change may be found in many individuals but then the mutational event happened early during the tissue culture period and was clonally multiplied into a number of descendants (Brettell and Dennis 1991; Kohli et al. 2004).

\section{Characteristics of epigenetic changes}

Epigenetic mechanisms include DNA methylation and modifications of amino acids in the tails of histones. Histones are proteins that package the DNA into nucleosomes and make up the chromatin in nuclei. DNA methylation and histone modifications interact and reinforce one another. In this way, transcription can be enhanced, for example, by acetylation of the lysine on position 9 of histone 3 ('H3K9'), which is found in promotor regions of actively transcribed genes. Transcription can also be decreased, for example, by di- and trimethylation of $\mathrm{H} 3 \mathrm{~K} 9$, which is a histone mark of repeat elements in the DNA (Bernatavichute et al. 2008; Tessadori et al. 2007). Repeat elements are also characterized by methylation of cytosines in the DNA.

This regulatory system has several functions. On the one hand, it is a defence mechanism against retrotransposons. Silencing of repeats is thought to occur in all cells, regardless of their location or developmental state. It is targeted by 21- and 24-mer short RNAs. Intriguingly, the same mechanism contributes to sustain the centromere through silencing and compacting the centromeric repeats
(Tessadori et al. 2007). On the other hand, epigenetic mechanisms regulate gene expression during development: genes may be methylated and switched off in some tissues, but demethylated and active in others (see Matzke et al. 2009 for a description of the mechanism and the genes involved). The clearest examples of this type of epigenetic regulation are found in mammalian embryogenesis: imprinting (where the activity of a gene in early embryo development depends on whether it is inherited from the father or the mother), X-inactivation (to achieve the proper gene dosage, one of the two $\mathrm{X}$ chromosomes in females is heavily methylated and transcription is largely switched off), and reprogramming (of genome-wide DNA methylation patterns in the gastrula stage). Imprinting also occurs during plant endosperm development (Hsieh et al. 2009). When 'genes' are said to be methylated and transcriptionally silenced, it is actually the promotor region that becomes methylated, as even actively transcribed genes may be methylated in the 'body' of the coding region, i.e., at some distance from the $5^{\prime}$ and $3^{\prime}$ end (Roudier et al. 2009; Tanurdzic et al. 2008).

During plant development, the epigenetic imprints provide a transient 'memory' of the developmental program and influence the cell's reactions and its future development (Roudier et al. 2009). A notable example of the memory function is vernalization, the acquisition or acceleration of the ability to flower by a chilling treatment. In Arabidopsis, vernalization involves the silencing of a group of flowering repressor genes, including Flowering Locus C (FLC; Bastow et al. 2004; Roudier et al. 2009). Silencing occurs during a cold period through an epigenetic 
change, viz., through histone modifications (Bastow et al. 2004; Kim et al. 2009). Interestingly, in barley it is mediated by different histone modifications at the floral activator gene VERNALIZATION1 (VRN1), allowing it to become active (Oliver et al. 2009) Another example is the phase change from juvenile to adult, which is paralleled by changes in gross DNA methylation (Valledor et al. 2007).

De Klerk (1990) and Vázquez (2001), amongst others, noted that the distinction between genetic and epigenetic changes is an oversimplification. Molecular evidence has accumulated showing that epigenetic changes may lead to many genetic abnormalities. The transposable element Activator (Ac) in maize looses DNA methylation and becomes activated upon dedifferentiation (Brettell and Dennis 1991). The same occurs in transgenic rice plants containing Ac from maize (Kohli et al. 2004). In maize, the activation is passed on for two sexual generations (Brettell and Dennis 1991). The miniature inverted repeat transposable element (MITE) mPing becomes activated in rice, e.g., in callus culture, which is correlated with alterations in cytosine methylation (Ngezahayo et al. 2009). The retroelement Tos 17 becomes active in rice suspension cultures, supposedly as a consequence of changes in the epigenetic modifications that silence it. As a result, plants regenerated from these cultures have many new copies inserted in their genome (Hirochika et al. 1996). The endogenous chromovirus LORE1a looses DNA methylation in dedifferentiated cells of Lotus japonicus, so that it can become active and transpose after regeneration. Strikingly, it only does so during pollen formation (Fukai et al. 2010). Insertions of transposable elements and retrotransposons can serve as insertional mutagens of plant genomes, whereas widespread activation can lead to a wide array of chromosomal rearrangements (Tanurdzic et al. 2008). These rearrangements can, in turn, lead to misregulation of genes, aneuploidy and new transposon insertions (Lee and Phillips 1988).

\section{Detection of epigenetic status}

For an accurate evaluation of the epigenetic status, both DNA methylation and chromatin modifications should be considered, and this should be done for particular genomic regions. Differences in genome-wide levels of DNA methylation are not very informative, as there can be massive local changes whereas overall levels are very similar. Measurement of the methylation of randomly chosen cytosines is inadequate since many changes may occur in DNA with no specific function. In addition, the methylation pattern of a stretch of DNA is important, usually not that of any particular cytosine by itself. As a consequence, changes in random sequences do not correlate with particular morphological or physiological abnormalities observed in regenerants (Jaligot et al. 2002; Smulders et al. 1995). Possible correlations between the amount of changes at the molecular level and the extent of abnormalities may be established by studying many more sites. Technically, such research is becoming possible. However, if specific stretches of DNA, e.g., in a particular promotor, affect the expression of a specific gene that leads to one type of change, an estimation of the overall level of variation would not necessarily provide a strong correlation with the specific abnormality under study.

It may be easier to study changes that occur repeatedly as the correlation of certain changes in DNA and histone modifications with the phenotypic changes can be determined and used as a selection criterion. In cancer research, this yields interesting results (certain aberrantly methylated $\mathrm{CpG}$ islands in the genome are biomarkers for several types of cancer). The progression of a cancer goes through several specific stages, including an initial step of massive DNA demethylation and subsequent selection for cell lines that manage to establish themselves. The changes induced by adventitious regeneration may not be so predictable, and the selection for abnormal lines not so severe, although examples exist where certain types of abnormalities occur at a relatively high level.

The methods to assess epigenetic status, either DNA methylation or histone modifications, are quickly developing (Fraga and Esteller 2002; Laird 2010; Vogel et al. 2009). For DNA methylation detection, various methods and protocols exist, including bisulfite treatment of DNA changes, which changes unmethylated cytosines into uracil but does not change methylated cytosines, and amplification after digestion of DNA with methylation-sensitive restriction enzymes (Gonzalgo and Jones 1997; Xiong and Laird 1997). Some researchers use antibodies against 5-methylcytosine (Barton et al. 2001). The methylationdependent restriction enzyme McrBC can be used to separate methylated from non-methylated DNA, followed by detection using whole genome microarray hybridisation (Vaughn et al. 2007). Bisulfite-treated DNA can be sequenced and compared to untreated DNA, thus producing detailed information on the methylation of cytosines on both strands of the DNA (Krizova et al. 2009; Zhang et al. 2009). Histone modifications are studied using chromatin immunoprecipitation (ChIP) of associated DNA followed by polymerase chain reaction (PCR) of cDNA or whole genome microarray hybridisation (Matarazzo et al. 2004; Roh et al. 2004; Shi et al. 2003). In this way, many known sites can be probed simultaneously.

Using a combination of these approaches a whole genome analysis of chromosome 4 of Arabidopsis thaliana was done on tiling microarrays by Tanurdzic et al. (2008). They generated detailed patterns of both DNA methylation 
and various modifications of the associated chromatin. They compared the epigenetic patterns of an immortalised cell suspension of Arabidopsis thaliana with that of the leaf cells from which the culture had been started. The heterochromatin had undergone dramatic DNA hypomethylation, which led to the transcriptional activation of certain transposable elements in culture, while other types of elements remained silent. The elements activated in culture had increased levels of 21-nucleotide small interfering RNAs, indicating interplay of RNA interference and histone modifications in epigenetic restructuring of the genome. Euchromatin, in which active genes reside, was hypermethylated in culture, but only a small percentage of genes obtained heterochromatic marks, which might lead to long-term silencing.

Krizova et al. (2009) studied the fate of an epigenetically silenced LO1 transgenic allele in tobacco taken through cell culture and regeneration from callus. They observed partial loss of Lo1E 35S promoter methylation compared with leaf tissue in the parent plant. In comparison, when starting with plants in which the promotor was not silenced, they observed an increase in promotor methylation in some regenerated plants. The data indicate that in the cell culture process the parental imprinting state was gradually lost. Bisulfite sequencing of the promoter in callus revealed molecules with no, intermediate, and high levels of methylation, demonstrating cell-to-cell methylation diversity in callus. Among regenerated plants the DNA methylation pattern was highly variable, but within a regenerated plant most cells were very similar in DNA methylation, indicating that the callus-induced epiallelic variants were transmitted to plants and had become fixed (Peredo et al. 2006). Dedifferentiation in cell suspensions and calluses of Arabidopsis thaliana led to hypermethylation of promoters of various genes. This hypermethylation in undifferentiated cells was associated with histone hypoacetylation (Berdasco et al. 2008). These changes were associated with transcriptional silencing of linked genes.

In the near future, next-generation sequencing will enable studying the detailed pattern of DNA methylation by sequencing bisulfite-treated DNA (Hsieh et al. 2009) or studying the effect of a treatment on histone modifications by comparing the DNA sequences associated with immunoprecipitated histones. Flusberg et al. (2010) managed to detect DNA methylation directly using single-molecule, real-time sequencing. These methods will be used to produce detailed overviews of epigenetic modifications among tissues and between developmental stages, in a variety of species. For a better understanding of the tissue culture process, the challenge will be to focus on relevant regions in the genome and to link the changes to the processes of dedifferentiation and differentiation. This may require sampling and studying time series of plant material while they proceed through the tissue culture process, as mature plants, and into future generations.

In tissue culture, adventitious regeneration is one of the main developmental pathways to obtain new plants. It is based on the ability of plants to redirect development (De Klerk 2009). To regain totipotency (the capability to generate a complete new plant) or pluripotency (the capability to generate an organ such as a root or a shoot), cells erase at least a part of the previous epigenetic marks. This process is called dedifferentiation. Accordingly, differences in regeneration capacity between genotypes may be brought about by differences in how fast and how easily epigenetic marks can be erased or reprogrammed. It has been hypothesised that cell type, developmental age, and physical age may affect the speed of reprogramming, and the accuracy of the process (Grafi 2004). Thus, epigenetic changes in adventitiously regenerated plants may be caused by incorrect, possibly incomplete, resetting of the epigenetic developmental program, much like what causes abnormalities in cloned mammals. Unfortunately, the dedifferentiation process is still not well understood. Dedifferentiation of specialized mesophyll cells of Arabidopsis thaliana into undifferentiated protoplasts leads to a dramatic reduction of heterochromatin with decondensation of all major repeats regions except the $45 \mathrm{~s}$ rDNA repeat (Tessadori et al. 2007). DNA methylation and histone H3K9 dimethylation do not change during the decondensation. The decondensation process is reversed in a stepwise way upon prolonged culturing. Tanurdzic et al. (2008) observed hypermethylation of euchromatic DNA in a long-term cell suspension of Arabidopsis thaliana that had lost the capacity to readily regenerate shoots. Law and Suttle (2005) observed rapid and reversible changes in DNA methylation and histone modifications in the course of 15 days after establishment of a potato cell suspension.

Tanurdzic et al. (2008) proposed that dedifferentiation initially involves the loss of epigenetic marks. Accordingly, the expression of maintenance DNA methylases, such as MET1 in Arabidopsis thaliana, is lower during the initial phase of a cell suspension culture. Subsequently, new epigenetic marks need to be established. Indeed, the expression of de novo DNA methylases and various histone modifying enzymes such as histone deacetylases (HDACs) is generally increased in tissue culture, while that of DNA demethylase ROS1 is lowered (Law and Suttle 2005; Tanurdzic et al. 2008). Mistargeted de novo methylation would allow the establishment and perpetuation of DNA hypermethylation of promoters, which would create epialleles, and hypomethylation of repetitive DNA, which may lead to activation of mobile elements. Krizova et al. (2009) examined the development of a tobacco cell culture into callus followed by plant regeneration. They observed the loss of parental imprinting in $25 \%$ of the regenerated tobacco plants, regardless of whether the epiallele was originally methylated or unmethylated. 
In micropropagation companies, the most frequently used tissue culture procedure involves inducing outgrowth of existing axillary buds by exogenous application of cytokinin or removal of the apical bud. It is generally believed that in this way very little or no genetic variation is induced (De Klerk 1990). Peredo et al. (2009) evaluated hop cultures with molecular techniques namely random amplified DNA polymorphism (RAPD), retrotransposon microsatellite amplified polymorphism (REMAP), and methylation-sensitive amplification polymorphism (MSAP). They did not detect any genetic variation between the original plants and propagated plants even after 12 cycles ( 2 years) of micropropagation. It should be noted that with molecular methods only a very small portion of the genome is screened, so there may actually still be abundant genetic changes. Epigenetic changes, though, were easily detected in these plants with molecular methods. Nearly $30 \%$ of the changes present in the polymorphic loci were shared by all in vitro plants. Lower levels of epigenetic variation were detected among plants from the different subcultures. The most common difference between field plants and in vitro plants was demethylation of cytosines in some restriction targets, representing $63 \%$ of the observed changes. Smýkal et al. (2007) used various molecular methods to assess the genetic stability of long-term (24 years) propagated shoot cultures of pea. No differences were found using microsatellite, inter-simple sequence repeat (ISSR) or inter-retrotransposon amplified polymorphism (IRAP) markers. However, amplification fragment length polymorphism (AFLP) and particularly methylation-sensitive amplification polymorphism (MSAP) detected 11 and $18 \%$ polymorphism, respectively. An examination of the global cytosine methylation status revealed no significant differences. Zeng et al. (2009) examined integration and expression level of transgenes during long-term micropropagation of transgenic birch. There was a stable integration of transgenes into regenerated plants, but expression levels of the transgenes among shoots subcultured 4, 7, 9 or 15 times were significantly different: the transcriptional expression level of transgenes decreased with increasing subculture number. The silencing rate of betaglucuronidase (GUS) in the fifth subculture plants was 22-65\%. 5-Azacytidine, a drug that causes global hypomethylation, reactivated transgene expression at 50-200 $\mu \mathrm{M}$, indicating that the decrease in expression level with increasing number of subcultures was associated with DNA methylation.

\section{Epigenetic changes of plants propagated in vitro: rejuvenation and habituation}

\section{Rejuvenation}

During their lifetime, plants pass through a developmental process referred to as 'phase change'. Immediately after germination plants are juvenile. They are unable to flower, even when the conditions are optimal. After some time, depending upon the species ranging from a few weeks to decades, plants become adult and capable of flowering. This phase change may be accompanied by morphological alterations such as changes in leaf shape and direction of stem growth. From the horticultural point of view, the change in the capability to root is important. Cuttings from the juvenile phase are usually easy-to-root while cuttings from the adult phase are recalcitrant. When adult buds are cultured in vitro, though, they often undergo the reverse change (rejuvenation) within a few subculture cycles. Rejuvenation becomes apparent as improved rooting (Webster and Jones 1989). The change in the ontogenetic phase is long-lasting: Cuttings taken from micropropagated plants that have been grown in the field, still have the improved capacity to root (Jones and Webster 1989). In birch, Jones et al. (1996) found that micropropagated trees flowered sooner than seedlings indicating that not all features of the micropropagated trees had become juvenile. The ontogenetic state (juvenile $v s$. adult) has been related to the methylation status of DNA. In Pinus radiata, for example, the extent of DNA methylation is higher in mature meristematic regions when compared to juvenile meristematic regions (Fraga et al. 2002). In addition, histone modifications (acetylation and methylation) play a major role (Valledor et al. 2010). Irish and McMurray (2006) observed that the cytosine methylation pattern of Pl-Blotched, an allele of purple plant1 (pl1), which encodes a myb-like transcription factor that regulates anthocyanin production in maize, in culture-rejuvenated plants resembled the hypomethylated state of seedlings, rather than the hypermethylated state in adult maize organs they were derived from.

\section{Habituation}

Plant tissues usually require auxin and cytokinin for continuous proliferation in tissue culture. In 1942, Gautheret reported that strains of carrot tissue gradually lost the requirement for exogenous auxin. This is referred to as auxin habituation. It was found later that habituation for cytokinin also occurs. Habituation is now defined more generally as a stable heritable loss in the requirement of cultured plant cells for growth factors (Meins 1989). The epigenetic nature of habituation is shown by the observation that plants regenerated from habituated cell cultures have the original requirement for hormones when cell cultures are established from them. The habituation shift occurs at rates that are orders of magnitude higher than mutations rates in plants (Meins 1989). One approach towards the identification of the mechanism of habituation is a comparison of gene expression in habituated and 
non-habituated cell cultures. A transcriptome-based analysis of habituated and non-habituated Arabidopsis thaliana plant cell cultures revealed the differential expression of more than 800 genes, including a 19-fold up-regulation of the transcript encoding the cytokinin receptor CRE1. The alterations in gene expression found among habituated and nonhabituated callus cultures do not result simply from global hypomethylation of DNA (Pischke et al. 2006). Nevertheless it has been reported that treatment of in vitro cultured cells of a nontumorous Nicotiana glauca $\times$ $N$. langsdorffii hybrid with 5-azacytidine, a drug causing hypomethylation, leads to the induction of a habituated phenotype (Durante et al. 1989).

\section{Epigenetic aberrations observed in micropropagated plants}

Commercial micropropagation operates since the 1970s1980s. The main advantages include high speed of propagation and production of disease-free, superior, clonal starting-material. During tissue culture, existing epigenetic differences may become visible, e.g., as the differential performance of buds taken from several positions on the same plant. Webster and Jones (1989) reported that two apple lines established from different buds at the same plant remained different with respect to propagation and rooting after a large number of subcultures. Similar observations were made with four lines of Helleborus $s p$. (G. de Klerk, unpublished observations). Baránek et al. (2010) reported differences in DNA methylation between lines established from different nodes on the same parent plant. In several crops unwanted epigenetic variation caused in tissue culture is a major drawback. Below we describe cases that have been examined in some detail.

\section{Bushiness in Zantedeschia and gerbera}

Zantedeschia is a relatively 'new' ornamental crop that is propagated in vitro on a large scale. The propagation factor is low, for many cultivars less than two per subculture cycle of 4 weeks (C. Randag, pers. comm.). To increase propagation, micropropagation companies have been using high cytokinin concentrations but in sensitive genotypes this resulted in bushiness after transfer to soil. Figure 2 shows bushy Zantedeschia plants. Bushiness is a long-lasting disorder and tubers that generate bushy plants in the first years after tissue culture also generate bushy plants during the following years. A cultivar that is sensitive to bushiness, Florex Gold, was most sensitive to cytokinin compared to other cultivars in a test in which the effect of cytokinin on root growth was determined (D'Arth et al. 2002), but there were no significant differences in cytokinin content between bushy and nonbushy plants (D'Arth et al. 2007). In this regard it should be noted that the conventional concept of hormonal control of apical dominance, involving only auxin as inhibitor and cytokinin as stimulator of outgrowth of axillary buds, is an oversimplification (Ongaro and Leyser 2008; Werbrouck and Debergh 1995). Zantedeschia is relatively prone to the induction of aberrations in tissue culture and various other aberrations occur such as large leaves (called "elephant ears") and genetic mosaic disease (Fig. 2).

Another case that has been studied in some detail is bushiness in gerbera. Anatomical analysis of longitudinal serial sections of bushy shoots shows that the apical meristem and the axillary buds have the same potential for further development, i.e., axillary bud primordia are not inhibited and develop instantaneously (Topoonyanont et al. 1999). The type of explant has a major effect on bushiness, the main shoot axis being the most sensitive. Higher cytokinin concentrations also enhance bushiness (Topoonyanont and Debergh 2001). Interestingly, addition of imazalil reduces bushiness. Imazalil is a fungicide that interferes with cytochrome P450 enzymes. These enzymes are involved in the metabolism of many xenobiotics and plant hormones.

\section{Tissue proliferation in rhododendron}

An abnormal phenotype has been observed in containergrown rhododendron cultivars initially propagated by tissue culture. This aberration has been named "tissue proliferation" and has also been found in azaleas and Kalmia latifolia. The plants display an abnormal tumourlike growth at or near the crown of the plant, and in some genotypes occasionally on aerial plant parts. The abnormal growth appears similar in morphology to crown galls, but tissue proliferation is not equal to crown gall development as Agrobacterium tumefaciens, the causal agent of crown gall, has not been detected. In some cultivars, the crown tumours produce shoots that are smaller than normal, with short internodes and a whorled arrangement of small leaves. In many affected cultivars the disorder is only observed during the first 1-3 years after initial propagation, resulting in significant financial losses for nurseries. Brand (2000) and Brand et al. (2000) reported that plants displaying tissue proliferation have an altered hormone metabolism or sensitivity. This change is apparently stable over many years but has disappeared after some 6 years. Higher cytokinin levels in vitro lead to a greater incidence of tissue proliferation in the field (Brand 2000).

Flower malformation in oil palm

Oil palm can be propagated via callus and somatic embryogenesis. Plants that have been generated in this 
Fig. 2 Various Zantedeschia off-types. The plants have been grown from T1 (D'Arth et al 2002) tubers. Normal (a); genetic mosaic (b); bushy plants (c); and "elephant ears" (d). (Photos were kindly provided by C. Randag MSc, 't Zand, The Netherlands.)
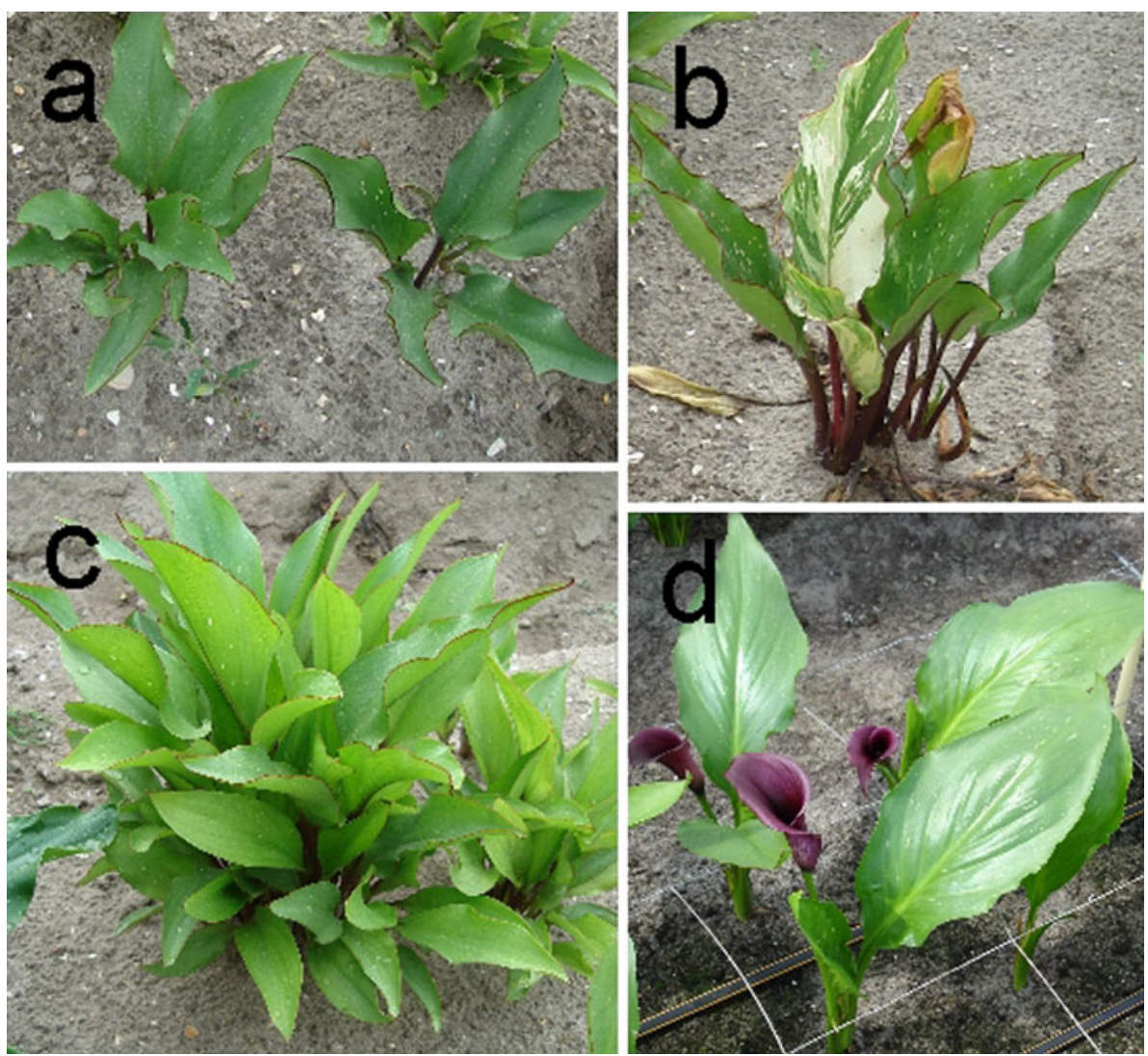

way, may show an aberration in their flowers, referred to as 'mantled'. These flowers develop a second whorl of carpels instead of stamens (Alwee et al. 2006). Most often the fruit does not develop properly (Corley et al. 1986) (Fig. 3). This causes a major financial loss, in particular as this abnormality is only detectable once palms start flowering, i.e., after 2 to 3 years in the plantation. Eeuwens et al. (2002) performed a careful study to find out which tissue culture conditions caused the malformed flowers and found that the disorder occurred more frequently in sensitive genotypes, when short subculture periods were used and when high cytokinin/low auxin was added. The disorder did not seem to be related with endogenous cytokinin levels (Jones et al. 1995). As this is typically a homeotic change, alterations in the homeotic genes that participate in the determination of floral organ identity should be considered (Alwee et al. 2006). Almost all of these are members of the MADS box transcription factor family. As the change occurs regularly, one would expect an epigenetic rather than a genetic change to underlie the abnormality. Indeed, although some genetic changes were found, these did not correlate with the occurrence of the morphological aberration (Matthes et al. 2001). Random DNA methylation changes were found among regenerated palms, and these did not correlate with the occurrence of the abnormality either (Jaligot et al. 2002).
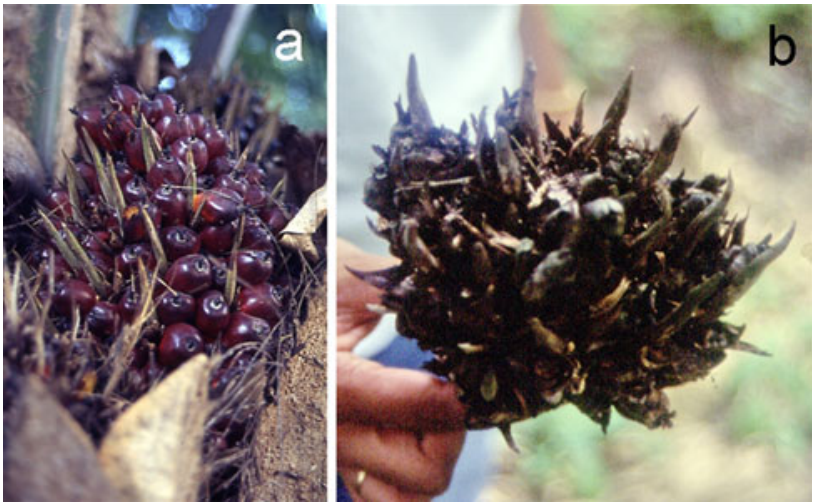

Fig. 3 A fruit bunch from a normal oil palm (a) and from a palm with aberrant, 'mantled' flowers (b)

\section{Leaf shape in begonia}

Searching for a method to quantify the extent of variation, De Klerk et al. (1990) determined the standard deviation of the leaf shape (measured as the natural logarithm of the ratio of length and width) in populations of regenerated plants. Plants had been regenerated either directly from leaves or after an intermediate callus phase at a high concentration of 2,4-dichlorophenoxyacetic acid (2,4-D). The leaf shape itself was the same in both populations but 
the standard variation of the leaf shape was far larger in the 2,4-D population. Addition of the chemical mutagens $N$-methylnitrosourea (NMU) during direct regeneration also increased the standard variation significantly. As the variation was random-in some plants the width of the leaves was increased and in others the length-, the detected variation was expected to be genetic. However, when new plants were produced by direct regeneration from the leaves of plants produced via callus, the standard variation of the leaf shape almost dropped to the value of the control. The plants produced after NMU treatment, though, displayed the same high level of the standard variation after adventitious regeneration. This indicates that the larger part of the variation in 2,4-D plants was epigenetic (Bouman and De Klerk 2001).

\section{Is epigenetic variation caused by stress?}

It was suggested above that epigenetic variation may be caused by incomplete resetting of epigenetic marks during adventitious regeneration, but there are likely additional origins. When plants experience stress, they show a multitude of responses, which may include epigenetic variation (Molinier et al. 2006). Oh et al. (2007) hypothesised that labile portions of the genome are affected by stress during micropropagation of Musa. Alterations in methylation have been reported in response to water deficiency (Labra et al. 2002), osmotic stress (Kovařik et al. 1997), heavy metals (Aina et al. 2004), and-in tissue culture-heat (Baránek et al. 2010). Some loci acquired epigenetic silencing, while sometimes silenced loci increased expression. It seems evident that 'extreme' procedures such as protoplast culture and also callus formation impose stress. However, for many species shoot culture may very well be stressful (De Klerk 2007; Desjardins et al. 2009; Van Staden et al. 2006). In this respect, it should be noted that in vitro, the tissues grow under very unnatural conditions: Plantlets have been wounded, they are incomplete (protoplasts being an extreme example), they receive sugar from the nutrient medium as a replacement of photosynthesis in the leaves, they receive high doses of auxins and cytokinins, and their water balance is disturbed by the very high humidity in tissue culture containers. Important questions needing answers are: To what extent can epigenetic variation be ascribed to 'stress'? Which of the tissue culture factors are most stressful? Answers to these questions may lead to procedures that result in a reduction of epigenetic variation. One possible improvement of the procedures is in the choice of cytokinin. In micropropagation usually benzylaminopurine (BAP) is added but another cytokinin, metatopolin, is often just as effective with respect to the breaking of apical dominance (so resulting in a similar propagation factor) but has less negative side-effects (Bogaert et al. 2006; Valero-Aracama et al. 2009; but see Bairu et al. 2008).

\section{Conclusions}

Long lasting changes in the expression of DNA are increasingly documented in plant development. They have been studied in relation to the ability to flower (vernalization) and the ontogenetic development from juvenile to adult. In these cases both methylation of DNA and alterations in histones have been shown to be involved. In plant tissue culture, changes in DNA methylation and in histone modifications have also been reported in many cases, ranging from protoplast formation to axillary shoot proliferation. Such changes are believed to underlie the generation of off-types, e.g., the mantled phenotype in oil palm and bushiness in Zantedeschia. Molecular research on well-defined off-types has been limited with the exception of oil palm. In oil palm, in spite of extensive research, molecular characterization of the aberration is still unsuccessful. This lack of insight in the molecular basis of epigenetic off-types impedes progress in the development of methods to avoid or counteract these aberrations.

Open Access This article is distributed under the terms of the Creative Commons Attribution Noncommercial License which permits any noncommercial use, distribution, and reproduction in any medium, provided the original author(s) and source are credited.

\section{References}

Aina R, Sgorbati S, Santagostino A, Labra M, Ghiani A, Citterio S (2004) Specific hypomethylation of DNA is induced by heavy metals in white clover and industrial hemp. Physiol Plant 121:472-480

Alwee SS, Van Der Linden CG, Van Der Schoot J, De Folter S, Angenent GC, Cheah SC, Smulders MJM (2006) Characterization of oil palm MADS box genes in relation to the mantled flower abnormality. Plant Cell Tissue Organ Cult 85:331-344

Bairu MW, Stirk WA, Doležal K, Van Staden J (2008) The role of topolins in micropropagation and somaclonal variation of banana cultivars 'Williams' and 'Grand Naine' (Musa spp. AAA). Plant Cell Tissue Organ Cult 95:373-379

Baránek M, Křižan B, Ondrušíková E, Pidra M (2010) DNAmethylation changes in grapevine somaclones following in vitro culture and thermotherapy. Plant Cell Tissue Organ Cult 101:11-22

Barton SC, Arney KL, Shi W, Niveleau A, Fundele R, Azim Surani M, Haaf T (2001) Genome-wide methylation patterns in normal and uniparental early mouse embryos. Hum Mol Genet 10:2983-2987

Bastow R, Mylne JS, Lister C, Lippman Z, Martienssen RA, Dean C (2004) Vernalization requires epigenetic silencing of FLC by histone methylation. Nature 427:164-167

Berdasco M, Alcázar R, García-Ortiz MV, Ballestar E, Fernández AF, Roldán-Arjona $\mathrm{T}$, Tiburcio AF, Altabella $\mathrm{T}$, Buisine $\mathrm{N}$, 
Quesneville H, Baudry A, Lepiniec L, Alaminos M, Rodríguez R, Lloyd A, Colot V, Bender J, Canal MJ, Esteller M, Fraga MF (2008) Promoter DNA hypermethylation and gene repression in undifferentiated Arabidopsis cells. PLoS ONE 3:e3306

Bernatavichute YV, Zhang X, Cokus S, Pellegrini M, Jacobsen SE (2008) Genome-wide association of histone H3 lysine nine methylation with CHG DNA methylation in Arabidopsis thaliana. PLoS ONE 3:e3156

Bogaert I, Van Cauter S, Werbrouck SPO, Doležal K (2006) New aromatic cytokinins can make the difference. Acta Hortic 725:265-270

Bouman H, De Klerk GJ (2001) Measurement of the extent of somaclonal variation in begonia plants regenerated under various conditions. Comparison of three assays. Theor Appl Genet 102:111-117

Brand MH (2000) Tissue proliferation on rhododendron: a current perspective. Comb Proc Intl Plant Prop Soc 50:295-298

Brand MH, Ruan Y, Kiyomoto R (2000) Response of Rhododendron 'Montego' with 'tissue proliferation' to cytokinin and auxin in vitro. HortScience 35:136-140

Brettell RIS, Dennis ES (1991) Reactivation of a silent Ac following tissue culture is associated with heritable alterations in its methylation pattern. Mol Gen Genet 229:365-372

Corley RHV, Lee CH, Law IH, Wang CY (1986) Abnormal flower development in oil palm clones. Planter 62:233-240

D'Arth SM, Simpson SI, Seelye JF, Jameson PE (2002) Bushiness and cytokinin sensitivity in micropropagated Zantedeschia. Plant Cell Tissue Organ Cult 70:113-118

D'Arth SM, Simpson SI, Seelye JF, Jameson PE (2007) Bushiness and cytokinin profile in dormant and sprouting tubers of Zantedeschia. Plant Cell Tissue Organ Cult 89:185-191

De Klerk GJ (1990) How to measure somaclonal variation: a review. Acta Bot Neerl 39:129-144

De Klerk GJ (2007) Stress in plants cultured in vitro. Propag Ornam Plants 7:129-137

De Klerk GJ (2009) Adventitious regeneration. In: Flickinger MC (ed) Encyclopedia of industrial biotechnology: bioprocess, bioseparation, and cell technology, vol 1. Wiley, London, pp 72-87

De Klerk GJ, Ter Brugge J, Bouman H (1990) An assay to measure the extent of variation in micropropagated plants of Begonia $\times$ hiemalis. Acta Bot Neerl 39:145-151

Desjardins Y, Dubuc JF, Badr A (2009) In vitro culture of plants: a stressful activity!. Acta Hortic 812:29-50

Durante M, Cecchini E, Natali L, Citti L, Geri C, Parenti R, Nuti Ronchi V (1989) 5-azacytidine-induced tumorous transformation and DNA hypomethylation in Nicotiana tissue cultures. Dev Genet 10:298-303

Eeuwens CJ, Lord S, Donough CR, Rao V, Vallejo G, Nelson S (2002) Effects of tissue culture conditions during embryoid multiplication on the incidence of "mantled" flowering in clonally propagated oil palm. Plant Cell Tissue Organ Cult 70:311-323

Flusberg BA, Webster DR, Lee JH, Travers KJ, Olivares EC, Clark TA, Korlach J, Turner SW (2010) Direct detection of DNA methylation during single-molecule, real-time sequencing. Nat Methods 7:461-465

Fraga MF, Esteller M (2002) DNA methylation: a profile of methods and applications. BioTechniques 33:632-649

Fraga MF, Rodríguez R, Cañal MJ (2002) Genomic DNA methylation-demethylation during aging and reinvigoration of Pinus radiata. Tree Physiol 22:813-816

Fukai E, Umehara Y, Sato S, Endo M, Kouchi H, Hayashi M, Stougaard J, Hirochika H (2010) Derepression of the plant chromovirus LORE1 induces germline transposition in regenerated plants. PLoS Genet 6:e1000868
Gonzalgo ML, Jones PA (1997) Rapid quantitation of methylation differences at specific sites using methylation-sensitive single nucleotide primer extension (Ms-SNuPE). Nucleic Acids Res 25:2529-2531

Grafi G (2004) How cells dedifferentiate: a lesson from plants. Dev Biol 268:1-6

Hirochika H, Sugimoto K, Otsuki Y, Tsugawa H, Kanda M (1996) Retrotransposons of rice involved in mutations induced by tissue culture. Proc Natl Acad Sci USA 93:7783-7788

Hsieh TF, Ibarra CA, Silva P, Zemach A, Eshed-Williams L, Fischer RL, Zilberman D (2009) Genome-wide demethylation of Arabidopsis thaliana endosperm. Science 324:1451-1454

Irish EE, McMurray D (2006) Rejuvenation by shoot apex culture recapitulates the developmental increase of methylation at the maize gene Pl-Blotched. Plant Mol Biol 60:747-758

Jaligot E, Beulé T, Rival A (2002) Methylation-sensitive RFLPs: characterisation of two oil palm markers showing somaclonal variation-associated polymorphism. Theor Appl Genet 104: $1263-1269$

Johannes F, Porcher E, Teixeira FK, Saliba-Colombani V, Simon M, Agier N, Bulski A, Albuisson J, Heredia F, Audigier P, Bouchez D, Dillmann C, Guerche P, Hospital F, Colot V (2009) Assessing the impact of transgenerational epigenetic variation on complex traits. PLoS Genet 5:e1000530

Jones OP, Webster CA (1989) Improved rooting from conventional cuttings taken from micropropagated plants of Pyrus comunis rootstocks. J Hortic Sci 64:429-434

Jones LH, Hanke DE, Eeuwens CJ (1995) An evaluation of the role of cytokinins in the development of abnormal inflorescences in oil palms (Elaeis guineensis Jacq.) regenerated from tissue culture. J Plant Growth Regul 14:135-142

Jones OP, Welander M, Waller BJ, Ridout MS (1996) Micropropagation of adult birch trees: production and field performance. Tree Physiol 16:521-525

Jullien PE, Berger F (2010) DNA methylation reprogramming during plant sexual reproduction? Trends Genet 26:394-399

Kim D-H, Doyle MR, Sung S, Amasino RM (2009) Vernalization: winter and the timing of flowering in plants. Annu Rev Cell Dev Biol 25:277-299

Kohli A, Prynne MQ, Miro B, Pereira A, Twyman RM, Capell T, Christou P (2004) Dedifferentiation-mediated changes in transposition behavior make the activator transposon an ideal tool for functional genomics in rice. Mol Breeding 13:177-191

Kovařik A, Koukalová B, Bezdĕk M, Opatrný Z (1997) Hypermethylation of tobacco heterochromatic loci in response to osmotic stress. Theor Appl Genet 95:301-306

Krizova K, Fojtova M, Depicker A, Kovarik A (2009) Cell cultureinduced gradual and frequent epigenetic reprogramming of invertedly repeated tobacco transgene epialleles. Plant Physiol 149:1493-1504

Labra M, Vannini C, Sala F, Bracale M (2002) Methylation changes in specific sequences in response to water deficit. Plant Biosyst 136:269-276

Laird PW (2010) Principles and challenges of genome-wide DNA methylation analysis. Nat Rev Genet 11:191-203

Law RD, Suttle JC (2005) Chromatin remodeling in plant cell culture: patterns of DNA methylation and histone $\mathrm{H} 3$ and $\mathrm{H} 4$ acetylation vary during growth of asynchronous potato cell suspensions. Plant Physiol Biochem 43:527-534

Lee M, Phillips RL (1988) The chromosomal basis of somaclonal variation. Annu Rev Plant Physiol Plant Mol Biol 39:413-437

Matarazzo MR, Lembo F, Angrisano T, Ballestar E, Ferraro M, Pero R, De Bonis ML, Bruni CB, Esteller M, D'Esposito M, Chiariotti L (2004) In vivo analysis of DNA methylation patterns recognized by specific proteins: coupling ChIP and bisulfite analysis. BioTechniques 37:666-673 
Matthes M, Singh R, Cheah SC, Karp A (2001) Variation in oil palm (Elaeis guineensis Jacq.) tissue culture-derived regenerants revealed by AFLPs with methylation-sensitive enzymes. Theor Appl Genet 102:971-979

Matzke M, Kanno T, Daxinger L, Huettel B, Matzke AJM (2009) RNA-mediated chromatin-based silencing in plants. Curr Opin Cell Biol 21:367-376

Meins F (1989) Habituation: heritable variation in the requirement of cultured plant cells for hormones. Annu Rev Genet 23:395-408

Molinier J, Ries G, Zipfel C, Hohn B (2006) Transgeneration memory of stress in plants. Nature 442:1046-1049

Ngezahayo F, Xu C, Wang H, Jiang L, Pang J, Liu B (2009) Tissue culture-induced transpositional activity of mPing is correlated with cytosine methylation in rice. BMC Plant Biol 9:91

Oh TJ, Cullis MA, Kunert K, Engelborghs I, Swennen R, Cullis CA (2007) Genomic changes associated with somaclonal variation in banana (Musa spp.). Physiol Plant 129:766-774

Oliver SN, Finnegan EJ, Dennis ES, Peacock WJ, Trevaskis B (2009) Vernalization-induced flowering in cereals is associated with changes in histone methylation at the VERNALIZATION1 gene. Proc Natl Acad Sci USA 106:8386-8391

Ongaro V, Leyser O (2008) Hormonal control of shoot branching. J Exp Bot 59:67-74

Peredo EL, Revilla MÁ, Arroyo-García R (2006) Assessment of genetic and epigenetic variation in hop plants regenerated from sequential subcultures of organogenic calli. J Plant Physiol 163:1071-1079

Peredo EL, Arroyo-García R, Revilla MÁ (2009) Epigenetic changes detected in micropropagated hop plants. J Plant Physiol 166:1101-1111

Pischke MS, Huttlin EL, Hegeman AD, Sussman MR (2006) A transcriptome-based characterization of habituation in plant tissue culture. Plant Physiol 140:1255-1278

Roh TY, Ngau WC, Cui K, Landsman D, Zhao K (2004) Highresolution genome-wide mapping of histone modifications. Nat Biotechnol 22:1013-1016

Roudier F, Teixeira FK, Colot V (2009) Chromatin indexing in Arabidopsis thaliana: an epigenomic tale of tails and more. Trends Genet 25:511-517

Shi H, Wei SH, Leu YW, Rahmatpanah F, Liu JC, Yan PS, Nephew KP, Huang THM (2003) Triple analysis of the cancer epigenome: an integrated microarray system for assessing gene expression, DNA methylation, and histone acetylation. Cancer Res 63:2164-2171

Smulders MJM, Rus-Kortekaas W, Vosman B (1995) Tissue cultureinduced DNA methylation polymorphisms in repetitive DNA of tomato calli and regenerated plants. Theor Appl Genet 91:1257-1264

Smýkal P, Valledor L, Rodríguez R, Griga M (2007) Assessment of genetic and epigenetic stability in long-term in vitro shoot culture of pea (Pisum sativum L.). Plant Cell Rep 26:1985-1998

Tanurdzic M, Vaughn MW, Jiang H, Lee TJ, Slotkin RK, Sosinski B, Thompson WF, Doerge RW, Martienssen RA (2008) Epigenomic consequences of immortalized plant cell suspension culture. PLoS Biol 6:2880-2895

Tessadori F, Chupeau MC, Chupeau Y, Knip M, Germann S, van Driel R, Fransz P, Gaudin V (2007) Large-scale dissociation and sequential reassembly of pericentric heterochromatin in differentiated Arabidopsis thaliana cells. J Cell Sci 120:1200-1208

Topoonyanont N, Debergh PC (2001) Reducing bushiness in micropropagated Gerbera. Plant Cell Tissue Organ Cult 67:133-144

Topoonyanont N, Ampawan R, Debergh PC (1999) Bushiness in Gerbera jamesonii: abnormal shoot development during micropropagation. J Hortic Sci Biot 74:675-679

Valero-Aracama C, Kane ME, Wilson SB, Philman NL (2009) Substitution of benzyladenine with meta-topolin during shoot multiplication increases acclimatization of difficult- and easy-toacclimatize sea oats (Uniola paniculata L.) genotypes. Plant Growth Regul 60:43-49

Valledor L, Hasbún R, Meijón M, Rodríguez JL, Santamaría E, Viejo M, Berdasco M, Feito I, Fraga MF, Cañal MJ, Rodríguez R (2007) Involvement of DNA methylation in tree development and micropropagation. Plant Cell Tissue Organ Cult 91:75-86

Valledor L, Meijón M, Hasbún R, Jesús Cañal M, Rodríguez R (2010) Variations in DNA methylation, acetylated histone H4, and methylated histone $\mathrm{H} 3$ during Pinus radiata needle maturation in relation to the loss of in vitro organogenic capability. J Plant Physiol 167:351-357

Van Staden J, Fennell CW, Taylor NJ (2006) Plant stress in vitro: the role of phytohormones. Acta Hortic 725:55-61

Vaughn MW, Tanurdžić M, Lippman Z, Jiang H, Carrasquillo R, Rabinowicz PD, Dedhia N, McCombie WR, Agier N, Bulski A, Colot V, Doerge RW, Martienssen RA (2007) Epigenetic natural variation in Arabidopsis thaliana. PLoS Biol 5:1617-1629

Vázquez AM (2001) Insight into somaclonal variation. Plant Biosyst 135:57-62

Vogel N, Schiebel K, Humeny A (2009) Technologies in the wholegenome age: MALDI-TOF-based genotyping. Transfus Med Hemother 36:253-262

Webster CA, Jones OP (1989) Micropropagation of the apple rootstock M9-Effect of sustained subculture on apparent rejuvenation in vitro. J Hortic Sci 64:421-428

Werbrouck SPO, Debergh PC (1995) Imazalil enhances the shootinducing effect of benzyladenine in Spathiphyllum floribundum schott. J Plant Growth Regul 14:105-107

Xiong Z, Laird PW (1997) COBRA: a sensitive and quantitative DNA methylation assay. Nucleic Acids Res 25:2532-2534

Zeng F, Qian J, Luo W, Zhan Y, Xin Y, Yang C (2009) Stability of transgenes in long-term micropropagation of plants of transgenic birch (Betula platyphylla). Biotechnol Lett 32:151-156

Zhang Y, Rohde C, Tieriing S, Jurkowski TP, Bock C, Santacruz D, Ragozin S, Reinhardt R, Groth M, Waiter J, Jeitsch A (2009) DNA methylation analysis of chromosome 21 gene promoters at single base pair and single allele resolution. PLoS Genet 5:e1000438 